\title{
The Recent U.S. Trade Deficit - No Cause for Panic
}

\author{
GEOFFREY E. WOOD and DOUGLAS R. MUDD
}

LARM has been mounting about the size of the U.S. trade deficit in 1977 and what seems in prospect for the deficit in 1978. The 1977 deficit has been described as the "largest in the Nation's history."1 It has been implied that the trade surpluses of other coun tries, which are the counterpart of the U.S. deficits, are in some way harmful.

There is no reason to believe that this pattern of accumulating surpluses for the oil exporters and chronic deficits for the oil importers will be reversed in the near future. The grim conclusion . . . is that the OPEC countries will continue to pile up excess reserves . . accumulating some $\$ 250-\$ 300$ billion in financial assets by $1980 .{ }^{2}$

It has been claimed that the deficit has "produced a loss in jobs."

Perhaps as a consequence of these fears, policy has increasingly come to focus on reducing one component of the trade deficit as a means of halting the decline of the dollar.

But the balance of trade is only one aspect of a country's international economic relations, and there are circumstances when a trade deficit is highly desirable. Further, the fear that a trade deficit will ag. gravate national unemployment is erroneous. In terms of national economic policy, the recommendation to reduce one component of the deficit so as to strengthen the dollar would not be helpful.

1Youssef M. Ibrahim, “\$26.7 Billion Trade Deficit, Fed by Oil Imports, Is Nation's Biggest," New York Times, January 31, 1978. The revised figure for the 1977 U.S. merchandise trade deficit is $\$ 31.2$ biltion.

2U.S. Congress, Senate Committee on Foreign Relations, Subcommittee on Foreign Economic Policy, "Intemational Debt, the Banks, and U.S. Foreign Policy," 95th Congress, 1st ses" sion, August 1977, p. 33 .

3U.S. Congress, Joint Economic Committee, Subcommittee on International Econonics, "Living With the Trade Deficit," 95 th Congress, 1st session, Novenber 18, 1977, p. 5 .

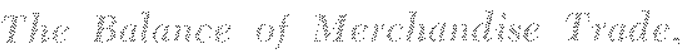

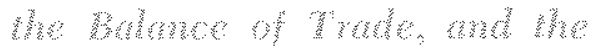

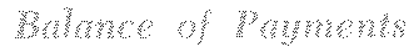

A country's exchange rate - that is, the value of its currency in terms of other currencies - will stay unchanged if the quantity of the currency supplied just equals the quantity demanded at the prevailing exchange rate. The exchange rate will rise when the quantity demanded exceeds quantity supplied and will fall when the quantity supplied exceeds quantity demanded.

Broadly speaking, the quantity of U.S. dollars supplied to foreign exchange markets in any year is made up of the dollars spent on imports, plus the amount of funds U.S. residents wish to invest outside the United States." The demand for U.S. dollars arises from the reverse of these transactions. Both exports by U.S. residents and the demand by foreigners to invest in the United States require that foreigners acquire dollars to spend in the United States.

Exports and imports comprise both goods (tangible items such as automobiles and wheat) and services (such as banking, insurance, transportation, and investment income). An export of services generates demand for dollars by foreigners just as does an export of goods, and the actual quantities involved in trade in services are very substantial. Net exports of these "invisibles" (as internationally traded services are known) in 1977 were $\$ 15.8$ billion, having grown fairly steadily from $\$ 0.7$ billion in 1966 .

As shown in Table $I$, net exports of services by the United States have, over the past few years, turned

4U.S. amporters supply dollars so as to purchase foreign currency to pay for imports, while investment abroad by U.S. residents creates demand for foreign currency because the foreign capital assets purchased - factories, stocks, government bonds, etc. - must be paid for in foreign currency. 


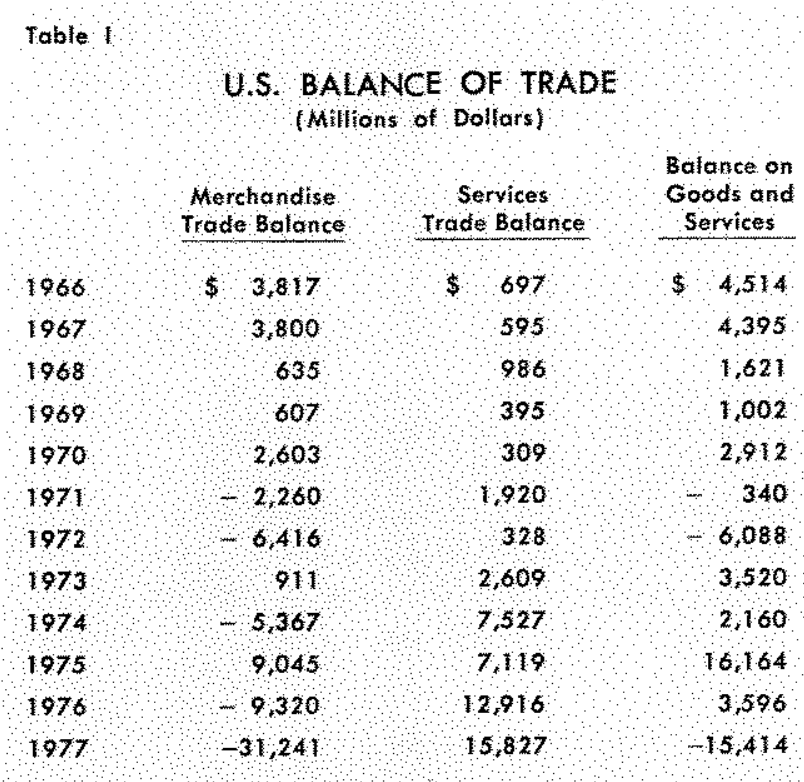

Sontes $U$ Q Depattment of Commere tor demand for dollars; the right hand side is the private sector supply.

Equation (1) can be rearranged in a number of ways; the most useful for the present purpose is as follows:

Exports - Imports = Capital Outfows - Capital Inflows (2)

This rearrangement of the equation helps one to see that a trade deficit must, as a matter of arithmetic, be accompanied by a net importation of investment funds, that is, a "capital inflow" in the terminology of balance of payments accounting. There cannot be one without the other; the United States cannot import funds without running a trade deficit. The balance of payments must always be in balance.

In the absence of government transactions undertaken with the aim of changing the exchange rate, the exchange rate will adjust until the private sector's supply of U.S. dollars on the exchange market equals the quantity of dollars demanded by the private sector in that market. ${ }^{B}$

The fact that a trade deficit (with an unchanged exchange rate) implies a net capital inflow is vital in seeing the economic significance of the current trade deficit.

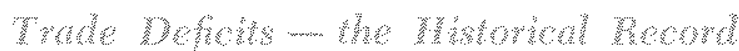

The United States ran a trade deficit for a substantial part of the 19th century. Table II shows tenyear annual averages of U.S. trade deficits, as percentages of Net National Product, for the years 1869 to 1908 , and for the years 1967 to 1977 on an annual basis. $^{7}$

A noteworthy feature is that, taken as a percentage of Net National Product, last year's deficit was not markedly large by 19th century standards. Another

\footnotetext{
fFor a discussion of official transactions and a distinction between when they are intended to infmence the exchange rate and when they are not, see Douglas R. Mudd, "International Reserves and the Role of Special Drawing Rights," this Review (Jamary 1978), pp. 10-I1.

TNNP is used in this comparison as this figure shows much better than GNP (which contains replacement investment) what is happening to national income after maintaining the nation's stock of real capital. Comparing the deficits to NNP, therefore, relates the deficits to what the nation can spend without depleting its accumulated stock of capital goods. (For the purpose of comparison, it may be useful to note that the 1977 deficit, 0.9 percent of NNP, is 0.8 percent of GNP.) Taking deficits as a percentage of NNP both compensates for inftation and zelates the deficit to the income which is avallable to service the change in indebtedness which a deficit implies. Comparisons of deffits as percentages of NNP are therefore the most appropriate form of comparison over long time periods.
} 
rable II

U.S. BALANCE OF IRADE RELATIVE TO NET NATIONAL PRODUCT

\begin{tabular}{|c|c|c|c|}
\hline Period: & $\begin{array}{l}\text { Bolante on } \\
\text { oods } \& \text { sentces } \\
\text { Mullons of } \\
\text { Dollars }\end{array}$ & $\begin{array}{l}\text { Net Notional } \\
\text { Product } \\
\text { (NND) } \\
\text { (Millons ot } \\
\text { Dollors) }\end{array}$ & $\begin{array}{l}\text { Balonee as } \\
\text { Bercent of } \\
\text { NINP }\end{array}$ \\
\hline 18691878 & 62 & 7,667 & $-0,8 \%$ \\
\hline 18791880 & 12 & 10,601 & -0 \\
\hline 18891890 & 4 & 12049 & 003 \\
\hline 18901908 & 353 & 20,540 & 17 \\
\hline 1967 & 4,395 & 729300 & 0.6 \\
\hline 1968 & 1,621 & 794700 & 02 \\
\hline 1969 & 1002 & 853100 & 01 \\
\hline 1970 & 2,912 & 891,600 & 0,3 \\
\hline 1971 & $\begin{array}{r}340 \\
\end{array}$ & 964,700 & 004 \\
\hline 1972 & - 6,088 & 10065800 & 0.6 \\
\hline 1973 & 3520 & $1,188,900$ & 0,3 \\
\hline 1974 & 2,160 & $1,275,200$ & 0,2 \\
\hline 1975 & 16,164 & $1,360,300$ & 12 \\
\hline 1978 & 3596 & $1,527,400$ & 0.2 \\
\hline 1977 & 15,414 & $1,693,100$ & 00 \\
\hline
\end{tabular}

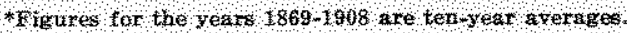

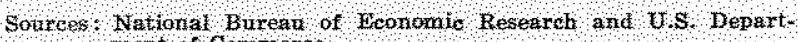
ment of Gounmeree

notable feature of the data in Table II is the shift to a trade surplus that occurred as the century progressed. This implies that the United States was moving from being a substantial net importer of investment funds to being a net exporter: ${ }^{8} \mathrm{~A}$ major reason for this is that in the earlier part of the period, the United States was expanding westwards at a very rapid rate. That created a demand for investment to construct transportation facilities, develop farmlands, and so forth. The rate of return that could be earned on capital in the United States was significantly higher than that which could be earned in the rest of the world. The economy thereby became more industrialized and agriculture more mechanized. Only as the United States became relatively abundant in capital, towards the end of the 19th century, did the situation change and the United States become a capital exporter.

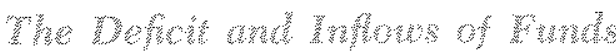

As Table II shows, the United States reverted to the position of a net importer of investment funds in

\footnotetext{
8These investment funds were, it should be noted, actually used in large part to buy capital goods from abroak in the 19 th century.
}

1977. The large increase in oil prices of recent years has provided some oil exporting countries with enormous ability to save out of current incomes. Naturally, they wish to invest these savings. That same increase in oil prices reduced spending power in the United States; people had to spend a larger portion of their incomes on oil, and had therefore less left for other purposes.

This means that it is quite rational for the United States to import investment funds at the present time; in other words, to attempt to borrow funds to pay for the increased imports. These funds allow U.S. consumers to adjust their consumption more smoothly they are not forced to make a sharp change, which is always unpleasant and can be inefficient since it forces cuts in what is easiest, rather than most desirable. ${ }^{9}$

Further, and ultimately more important, the inflow of funds can make it easier for U.S, firms to invest. The inflow of funds represents an increase in the demand for U.S. securities. Unless the supply of these securities rises by at least the same amount as the increase in demand, the price of U.S. securities is bolstered by this inflow of investment funds, and U.S. interest rates are lower than they would otherwise have been. ${ }^{10}$ This increased ease in obtaining funds helps firms to invest, and thus encourages long-run growth in output, which is the only way the decline in U.S. living standards caused by the oil price increase can ultimately be reversed. Without the in flow of funds from the oil exporting countries, living standards would be lower and prospects of raising them bleaker than with the inflow.

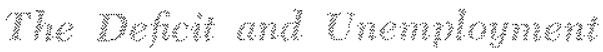

Imports do not cause unemployment. Many imports into the United States are themselves used in U.S. exports. An example is imported steel. Steel can be obtained more cheaply abroad than in the United States, and the prices of U.S. exports which use steel reflect the lower input price. Restrictions designed to raise import prices would also raise U.S. export (and domestic) prices for those goods, as well as directing

\footnotetext{
${ }^{9}$ An example is a family which bought a new automobile just before the oil price increase. The family might want to change to one which used less gas, but initially would be stuck with the car and have to cut back on, say, clothing.

10It should be emphasized that there is not necessarily a net increase in investment as compared to what would have happened without the oil price increase. There is an increased incentive to invest, as compared to the hypothetical situation where oil prices had increased but there had been no inflow of funds from abroad.
} 
to the production of steel resomces which would more profitably be used elsewhere. The increase in U.S. expot prices relative to wold market prices would reduce U.S. exports and, hence, U.S. export production and U.S. employment in some exporting industries.

Imports into the United States also create income abroad. If imports were suddenly restricted, U.S. exporters would experience an associated drop in demand. Agriculture, an industry currently eager to export so as to boost income, is an example of an industry highly sensitive to foreign demand for its products.

Hence, imports create some job opportunities as part of the very process by which they reduce others. But, even if the United States used more labor in producing every good than any other country in the world, it would still be possible for the United States to participate in foreign trade, to gain from that trade, and not to suffer unemployment as a result.

That proposition is by no means new. It was demonstrated first in 1817 by the economist and stockbroker David Ricardo. Briefly, the reason why trade cannot permanently cause unemployment is that when workers are displaced from one job by competition from elsewhere, they can move on to another job. It does not matter whether the competition is at home or abroad. If some goods are being produced and sold more cheaply than before, consumers, and also profucers of these goods, have increased income and thereby increased demand for other products. ${ }^{11}$

That is not of course to say that engaging in international trade camnot cause a temporary fluctuation in unemployment. There can be temporary unemployment as workers move around while some industries expand and others decline. ${ }^{12}$ But if trade is restricted to eliminate that type of unemployment, the economy is frozen in a wasteful pattem of production, just as if, when the automobile started to displace the horse

\footnotetext{
11 A more defailed demonstration is contaned in the screened insert accompanying this article. The demonstration given there is essentially Ricardo's. As his proof considers only the labor which is involved in production, it is particularly well-suited to show the effect of trade on employment. See David Ricardo, The Principles of Political Economy and Taxation (London; I, M. Dent \& Sons, Ltd., reprinted 1948), pp. $77-93$

${ }^{12}$ Workers would also have to move aroune if a contry pegged its exchange rate despite having a higher rate of inflation than its trading partners. They would have to do so because pegging the exchange rate would depress both exportingt and import-commeting industries. Pegging the exchange rate can therefore cause unemployment, but this, too, wotld be temporary.
}

and carriage, automobile production had been made illegal to protect the carriage-making industry. ${ }^{13}$

Accordingly, a trade deficit cannot permanently cause unemployment, if there are no domestic restrictions on labor mobility. A trade deficit can be accompanied by temporary unemployment as workers move from one job to another, but protecting the old jobs is both unnecessary and hamful to national prosperity. (It is most certainly understandable that workers resist having to move from one job to another; such moving can be expensive and inconvenient. But it is in no one's interest for them not to move.)

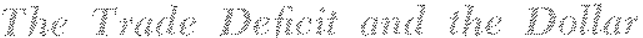

Eliminating any one part of U.S. imports, even one equal to the deficit, would not do much to prevent the fall in the dollar's foreign exchange value. For example, if the United States suddenly stopped importing oil, it would lose a nearly equivalent dollar inflow from the oil-producing countries, and there would be little net effect on the balance of supply and demand for dollars on the foreign exchange markets. ${ }^{14}$

As a further example, if the United States suddenly stopped importing foreign automobiles, there would be increased demand for domestic automobiles. Thus, resources would be diverted from the production of exports, and income would also of course be reduced abroad, thereby reducing the demand for U.S. exports. Again the overall effect on the foreign exchange market is unlikely to be large. Nor would the United

13There are vory special circumstances when it may be adm visable to provide assistance to smooth the decline of an industry; btt that assistance should never take the form of trade restriction, and shoul never aim to actually prevent the declme. "The aryments for this can be found in Geoffrey E. Wood, "Serile Industry Protection: Conment," Southem Economic Joumal (January 1975), pp. 535-37.

14 At the end of 1977 , U.S. banks reported liabilities of abont $\$ 9$ billion to Niddle East oil exporting countries. These combries also made net purchases of U.S. corporate stocks and bonds and marketable U.S. Treasury bonds and notes totalling about $\$ 7.5$ billion during $197 \%$. Further, stonce these figures onit purchases of land and buildings, they understate the capital intlow. Another large part of OPEC revenue from the United States (some 3 to percent) is spent on U.S. goods. (As noted by Clifton B. Luttuell, "Free Trade: A Major Factor in U.S. Farm Incone," this Review (March 1977), p. 23 , agricultural exports rose considerably as a resalt of OPEC price rises.) Total OPEC spending in the Tnited States is aso understated by the amount of U.S. net exports of services to the oil exporting countries. There is good reason for thinking this understatement to be substantial in view of the large jump in U.S. net exports of services after the first major oil price increase. Thus, the simple arithutetic does not support the clam that U.S. imports of on have produced on foreigu exchange markets all the excess suppty of dollars which has caused the decline of the dollar's foreign exchange value. 


\section{Labor Mobility, The Benefits from Trade, and Employment}

For the sake of exposition, we can assume that there are only two countries, the United States and the rest of the world, and, for simplicity, that there are only two goods, wheat and cloth. In the presence of competition, the price of wheat relative to the price of eloth will be equal to their relative production costs. Suppose that production of a unit of cloth reauires the labor of 120 workers for one year in the United States, and that a unit of cloth can be pro dueed hithe rest of the world' with the labor of 80 workers for one year. Production of a given guantity of wheat in the United States requires the labor of 100 workers for a year, while the same quantity of wheat conld be produced in the rest of the wold? with the labor of 90 workers for a year. Thus, the production of both cloth and wheat requires a smaller expenditure of labor in the rest of the world than in the United States.

With habor being the only cost of production and with competitive markets, in the absence of trade the relative price ratio of wheat to cloth in the United States would be equal to the ratio of labor trputs that is, it would be $100 / 120(-5 / 6)$, The corresponding price ratio in the rest of the world would be $90 / 80(=9 / 8)$

If trade between the United States and the rest of the world ${ }^{2}$ opens up, the Unted States will impott doth and export wheat The reason is as follows. At the rest of the worlds ${ }^{2}$ price ratio, $9 / 8$, the United States could exchange one umit of wheat for $9 / 8$ units of doth, Hence, the United States could employ 100 workers to produce a unit of wheat and exchange the Wheat for a quantity of cloth which would have required the labor of 135 workers to produce domes tically. Further, the rest of the world" could employ 80 workers to produce a unit of cloth and exchange it,

States have "gained jobs". There would be an increase in the number of jobs in automobile production, but reduced job opportunities in those industries where foreign demand had fallen. Further, such trade restrictions will divert U.S. resources to activities more productively carried out abroad. Piecemeal attacks on the trade deficit will not achieve an improvement in the balance of payments on any significant scale.

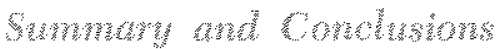

Present concern about the U.S. trade deficit is much greater than the facts justify. When all trade, and not just merchandise trade, is examined, the deficit is, by historical standards, not outstandingly large. Futhermore, the deficit has a most desirable feature. It allows the United States to import investment funds. At the at U.S. prices, for $6 / 5$ units of wheat Thus, the rest of the world could obtain an amount of wheat, which would have required the labor of 108 workers to produce domestically, for one unit of cloth which it produced by the labor of 80 workers:

As production of wheat in the United States nises (and production of cloth declines), workers move out of the U.S, cloth industry and into the wheat industry, Workers in the rest of the world on the other hand, move out of the wheat industry and into the cloth indistry, As a result of trade both the United States and the rest of the world gain in that both countries obtain a unit of each good for a smaller resource expenditure than would be required to prodice the same amount of goods $1 \mathrm{n}$ the absence of trade, and can therefore consume (or livest) nore. Although the rest of the world' has been assumed to use less yesources in producing every good than does the United States, it still benefits fiom buying goods produced in the United States.

The example shows that in the absence of restric tons on labor moving from one industry to another within $a$ eountry, all who want 10 work will find en ployment, even in a country where production costs are higher than those in the rest of the world Further, it also shows that as a consequence of trade they will be better oft than they would be without trade. This anses because they specialize according to whatever hey can best do. This, of eourse, is what individuals Who wish to maxmize their income do on their own initfative.

For the sake of brevity, the example speaks of numbers of workers. If wages are higher in one country than in another, this is dealt with by specifying the example in termis of "value-equivalent". labor units The same result holds.

moment this is desirable from the point of view of both the United States and the countries which are supplying those funds.

The deficit has at most a transitory effect on the overall level of employment in the United States. Jobs will be lost in some industries, but gained in others. So long as resources, including labor, can move fairly freely, a trade deficit does not reduce the overall level of employment. Analysis which points to particular activities which are eliminated as a result of engaging in foreign trade, and then concludes that trade has led to a loss of jobs, implicitly assumes that once resources are in place they can never again move. There are instances when artificial barriers restrict these movements, but the problems that arise are due to these barriers and not to the deficit. 
Finally, and perhaps most important, measures aimed at eliminating some particular component of the trade deficit would produce wasteful uses of resources, have little effect on the balance of payments, and therefore make little contribution to arresting the slide in the dollar's foreign exchange value. Panic attacks on individual components of the trade deficit will do much harm and little good.

\section{APPENDIX}

Merchandise Trade Balance:

Goods and Services Balance:

Current Account Balance:

Capital Account:
Exports of goods less imports of goods. Fxported agricultural products accounted for about 20 percent of total U.S. merchandise exports in 1977. Imported petroleum accounted for about 30 percent of total U.S merchandise imports in 1977.

Merchandise trade balance plus net exports of services. Internationally "traded" services include banking, insurance, transportation, tourism, military purchases and sales, and receipts of earnm ings on investments abroad. United States exports of services have exceeded imports for the past 16 years.

Goods and services balance less unilateral transfers. Unilateral transfers include private gifts to foreigners and government foreign assistance grants but exclude military grants. U.S. unilateral transfers to foreigners have averaged about $\$ 4.5$ billion per year since 1970 .

Includes changes in U.S, investment abroad and changes in for-
Capital Account: eign investment in the United States. Purchases of foreign (U.S.) government securities and corporate bonds and stocks are examples of U.S. (foreign) investment abroad (in the United States). An increase in U.S. investment abroad represents a capital outflow (entered into balance-of-payments accounts as a negative item). An increase in foreign investment in the United States represents a capital inflow (entered as a positive item), Since changes in U.S. investment abroad, and foreign investment in the United States, include changes in official reserve assets (such as purchases of U.S. Treasury securities by foreign central banks), the capital account and current account must offset each other (a balancing category, "statistical discrepancy," is required to produce an exact offset in the reported data). Thus, with a carrent account deficit of $\$ 20.2$ billion in 1977, the United States recorded a net capital inHow of $\$ 23.2$ billion (and hence a "statistical discrepancy" figure of $\$-3.0$ billion).

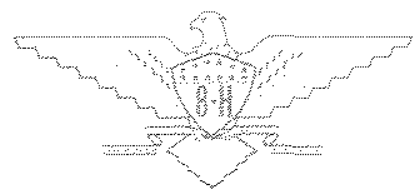

